\title{
Diabetes ketoacidosis in L-asparaginase therapy
}

\author{
Marichu P Mabulac', Carol Boongaling, Lorna R Abad \\ From 7th APPES Biennial Scientific Meeting \\ Nusa Dua, Bali. 14-17 November 2012
}

\section{Background}

Diabetic ketoacidosis as a complication of $\mathrm{L}$ asparaginase therapy in children with acute leukemia is rare. We report a patient with acute lymphoblastic leukemia who developed diabetic ketoacidosis while on treatment with L-asparaginase.

\section{Case}

E.C, 10 years old female brought to the ER due abdominal pain. Patient is a diagnosed case of B-Cell Acute Lymphoblastic Leukemia (ALL) thru clinical symptoms, laboratory work-ups and flow cytometry since 2 months prior to her present admission. She has been receiving 8 doses of L-asparaginase (leunase) and Prednisone $(60 \mathrm{mg} /$ day for a week then $40 \mathrm{mg} /$ day for 3 weeks) for almost one month before this recent admission. One week prior to hospitalization, the patient had nocturia (2-3x/night), polyuria and polydipsia. On the day of admission, she had sudden onset difficulty of breathing associated with severe abdominal pain and vomiting. She came in non-ambulatory, in cardiorespiratory distress with BP: 100/70mmHg, HR: $150 / \mathrm{min}$, RR: $60 / \mathrm{min}$, Temp: $37.3^{\circ} \mathrm{C}$. Pertinent physical exam showed signs of dehydration with abdominal tenderness, and signs of circulatory compromise. Fluid resuscitation was immediately instituted. The initial assessment at the ER was pancreatitis but the serum amylase and lipase were normal. Other lab work-ups showed blood glucose of 26.8 $\mathrm{mmol} / \mathrm{L}(\mathrm{NV}: 3.08-7.92)$, sodium at $115 \mathrm{mmol} / \mathrm{L}(\mathrm{NV}: 132-$ 143), potassium of 3.3, Chloride at $88 \mathrm{mmol} / \mathrm{L}$ (NV: 98 116). Blood gas showed ph of 7.1, a pCO2: $50, \mathrm{HCO} 3$ at 3.7 , and a base deficit of $-22.5 \mathrm{mmol} / \mathrm{L}$. Urinalysis showed +4 of glucose and +3 of ketones. The patient was then managed as a case of DKA and fluid resuscitation was continued and insulin drip was started. The haemoglobin A1c level at diagnosis was $11.4 \%$ but the C-peptide was normal. Patient condition improved and was discharged with insulin injection. The insulin was discontinued after

Section of Pediatric Endocrinology, Department of Pediatrics, University of the Philippines-Philippine General Hospital, Manila, Philippines

completion of her induction phase and with normalization of blood glucose.

\section{Conclusion}

Early recognition of the precipitating factors for DKA is important to prevent L-asparaginase fatal consequences, and the leukemic process itself maybe considered as one of the predisposing factors.

Published: 3 October 2013

doi:10.1186/1687-9856-2013-S1-P21

Cite this article as: Mabulac et al:: Diabetes ketoacidosis in L-

asparaginase therapy. International Journal of Pediatric Endocrinology 2013 2013(Suppl 1):P21.
Submit your next manuscript to BioMed Central and take full advantage of:

- Convenient online submission

- Thorough peer review

- No space constraints or color figure charges

- Immediate publication on acceptance

- Inclusion in PubMed, CAS, Scopus and Google Scholar

- Research which is freely available for redistribution
() Biomed Central

\section{Biomed Central}

